\title{
PRZEŁAMANIE REZULTATÓW WYKŁADNI JĘZYKOWEJ ZGODNIE Z ZASADĄ NADRZĘDNOŚCI KONSTYTUCJI
}

Przedmiotem artykułu jest analiza dopuszczalności przełamania rezultatów wykładni językowej przez odejście od alternatyw interpretacyjnych wynikających z możliwego sposobu rozumienia wyrażeń użytych w treści przepisu, na podstawie reguły nadrzędności konstytucji. Celem artykułu jest więc zbadanie problemu, czy stosując prawo, można pominąć jednoznaczną treść ustawy, jeżeli jej zastosowanie prowadzi do rezultatów niezgodnych z konstytucją. Problem przełamania jednoznacznych rezultatów wykładni językowej pozostaje bezpośrednio powiązany z kontrowersjami odnoszącymi się do dopuszczalności stosowania $\mathrm{w}$ omawianym przypadku reguły lex superior derogat legi inferiori jako reguły pozwalającej rozstrzygać konflikty między sprzecznymi normami.

Już na wstępie należy wskazać, że to, czy istnieje granica językowej interpretacji tekstu prawnego, jest z punktu widzenia filozofii języka zagadnieniem spornym ${ }^{1}$. Zarówno intuicja, jak i praktyka wskazuja jednak, że sposób rozumienia określonych wyrażeń we wspólnocie interpretacyjnej oraz uwarunkowania historyczne związane ich użyciem ograniczają w pewien sposób akceptowalne możliwości ich wykładni. Powyższą okoliczność można zilustrować przykładami. Rozważając na gruncie językowym, kim jest osoba prowadząca działalność gospodarcza, trudno byłoby uznać, że jest nią emeryt, który otrzymuje wyłącznie środki od państwa. Gdy przepis posługuje się pojęciem osoby prawnej, wątpliwe będzie przyjęcie, że dotyczy on osób fizycznych. Już dwa przywołane przykłady obrazuja, że analizując treść przepisu, można wyróżnić pewien powszechnie akceptowany katalog zjawisk, które ewidentnie nie mieszczą się w zakresie wyrażeń użytych przez ustawodawcę w tekście aktu prawnego. Nie wdając się w szczegółową analizę problemu, gdzie dokładnie leży językowa granica wykładni, w artykule poddaję weryfikacji, czy - a jeżeli tak, to w jakich sytuacjach - możliwe jest jej przełamanie zgodnie z zasadą nadrzędności konstytucji.

\section{ROLA KONSTYTUCJI I CHARAKTER JEJ NORM}

Przepisom konstytucji przypisuje się dziś powszechnie normatywny charakter $^{2}$. Oznacza to, że nie mają one jedynie charakteru politycznej deklaracji, ale stanowia fundament polskiego systemu prawnego. Konstytucja zawiera

\footnotetext{
${ }^{1}$ Zob. Spyra (2006): 142-183.

${ }^{2}$ Zob. m.in. Gutowski, Kardas (2017): 501 wraz z przywołaną tam literatura; Tuleja (2016): 74.
} 
przy tym normy różnego rodzaju. Przykładowy ich podział zakłada wyróżnienie norm proceduralnych - regulujących formę postępowania podmiotów wymienionych w konstytucji i wskazujących elementy, które pozwalają uznać ich postępowanie za wywołujące skutki prawne, a także materialnych - determinujących cele i treść działania tych podmiotów, regulujące granice i program działalności państwa, zasady jego ustroju oraz stosunki pomiędzy nim a jednostkami ${ }^{3}$.

Ze względu na zróżnicowany charakter norm konstytucji jedynie część z nich ma charakter precyzyjny. Wiele regulacji ma charakter kierunkowy, opiera się na pojęciach niedookreślonych bądź stanowi swoiste klauzule generalne. Nie zmienia to faktu, że nawet takie przepisy zachowują swój normatywny charakter ${ }^{4}$, a co za tym idzie, niewątpliwie powinny być uwzględniane w procesie wykładni innych przepisów prawa. W szczególności, mimo generalnego charakteru wielu przepisów konstytucyjnych, nie budzi wątpliwości, że włączone tymi przepisami do systemu prawnego wartości stanowią podstawę aksjologiczną funkcjonowania całego systemu prawnego, która winna być uwzględniana $\mathrm{w}$ procesie stanowienia i stosowania prawa ${ }^{5}$. W szczególności konstytucyjne fundamenty, takie jak np. „sprawiedliwość” czy „obowiązek poszanowania godności ludzkiej”, powinny być uwzględniane przez każdego interpretatora w procesie wykładni ustawy.

\section{ZNACZENIE TEKSTU PRAWNEGO}

Fakt, że prawo w Polsce, podobnie jak w innych krajach systemu prawa stanowionego, przyjmuje postać pisemnych aktów normatywnych, sprawia, że kluczowego znaczenie nabiera tekst aktu prawnego. To do niego w pierwszej kolejności sięga każdy interpretator, by ustalić treść obowiązującego prawa. Stosowanie prawa wymaga przy tym poddania tekstu prawnego procesowi wykładni, którego istotnym elementem, w świetle współczesnych koncepcji wykładni $^{6}$, pozostaje odczytanie znaczenia zawartych w przepisie wyrażeń, ustalenie ich sensu? ${ }^{7}$. Skutkiem interpretacji regulacji jest przełożenie treści

${ }^{3}$ Banaszak (1997): 116.

4 Banaszak (2012): 84-85.

5 Tak m.in. Gutowski, Kardas (2017): 226 - „Nie ma wątpliwości, że z uwagi na nadrzędną rolę Konstytucji proces wykładni musi być uporządkowany w taki sposób, by gwarantować, że ostateczny rezultat czynności interpretacyjnych w postaci w pełni zrekonstruowanej treściowo i zakresowo normy nie będzie pozostawał w żadnym aspekcie w sprzeczności z normami konstytucyjnymi. Ponadto nadrzędna rola Konstytucji jako źródła prawa przesądza o tym, że wyrażone w niej założenia aksjologiczne systemu prawa muszą być uwzględniane w procesie wykładni, tak by ostatecznie zdekodowane z przepisów prawa normy odzwierciedlały w najwyższym z możliwych stopniu konstytucyjne wartości i aksjologię".

${ }^{6}$ Wróblewski (1990): 58-59; Zieliński (2017): 290-297.

7 Pojęcie wykładni przepisów nie jest przy tym interpretowane jednoznacznie - zob. Gutowski, Kardas (2017): 232 wraz z przywołaną tam literatura. 
przepisu na normę prawną ${ }^{8}$, rozumiana jako nakaz lub zakaz jakiegoś postępowania ${ }^{9}$. Ponieważ treść prawa zawiera się w aktach normatywnych opartych na słowie pisanym, oczywiste jest, że wykładnia prawa musi rozpoczynać się od analizy językowej treści aktu normatywnego.

Zastosowanie wykładni językowej nie zawsze da jednoznaczne rezultaty. Niejednokrotnie bowiem na gruncie językowym możliwe jest odczytanie tekstu prawnego na szereg różnych sposobów. W takiej sytuacji doktryna istotne znaczenie przypisuje wykładni funkcjonalnej i systemowej, wskazując, że może ona służyć do rozstrzygnięcia, którą z alternatyw interpretacyjnych należy w danym przypadku przyjąc ${ }^{10}$. Nie budzi wątpliwości, że zasada hierarchiczności norm systemu prawnego oraz nadrzędności konstytucji może posłużyć do odrzucenia części hipotez interpretacyjnych, chociażby ze względu na fakt, że taka wykładnia prowadziłaby do naruszenia wartości konstytucyjnych ${ }^{11}$.

Problematyczne pozostaje jednak, czy kryteria funkcjonalne i systemowe moga służyć do przekroczenia granic możliwego językowego sposobu rozumienia tekstu prawnego. W szczególności spory rodzi to, czy w procesie wykładni prawa dopuszczalne pozostaje odstapienie od stosowania jednoznacznie brzmiącego przepisu ustawy w sytuacji, gdy jego zastosowanie pozostawałoby sprzeczne z konstytucją ${ }^{12}$.

\section{SPORY O ROZUMIENIE ZASADY BEZPOŚREDNIEGO STOSOWANIA KONSTYTUCJI}

Omówienie wskazanych sporów wymaga nawiązania do zasady bezpośredniego stosowania Konstytucji. Zasada ta wynika z art. 8 ust. 2 Konstytucji RP, zgodnie z którym jej przepisy stosuje się bezpośrednio, chyba że ustawa zasad-

8 Ilustracją tego stwierdzenia może być fakt, że w polskim prawie nie znajdziemy przepisu stanowiącego „nie wolno zabijać innego człowieka”, a jedynie regulację stanowiącą o karze, której podlega osoba dopuszczająca się zabójstwa. Wyprowadzenie z przepisu normy postępowania wymaga więc jego interpretacji.

9 Za szczególną kategorię takich norm można uznać normy kompetencyjne - zob. Ziembiński (1969): 23-41.

${ }^{10}$ Wydaje się, że interpretator, zapoznając się z treścią przepisu i starając się go rozumieć, stosuje równocześnie wykładnię językowa, celowościową i funkcjonalną. Interpretując sens użytych przez ustawodawcę słów, zastanawia się on, jakie jest ich możliwe znaczenie, jaki cel mógł chcieć osiagnąć ustawodawca za ich pośrednictwem. Czytając przepis, odrzuca on te znaczenia słów i wyrażeń, które nie pozwalają nadać regulacji rozsądnego znaczenia lub które pozostają nie do pogodzenia z zasadami funkcjonowania systemu prawnego.

11 Garlicki (1999): 24-26.

12 Wiele regulacji konstytucyjnych nie ma charakteru precyzyjnego i stanowi „semantycznie otwarte" zasady, w ujęciu Alexego (2010): 78. Wykładnia przepisów je zawierających wymaga uwzględniania szerokiego otoczenia normatywnego konstytucji, obejmującego w szczególności stojące za nią idee ustrojowe - zob. Wronkowska (2016): 23-27. Okoliczność ta nie zmienia tego, że - w mojej ocenie - może dojść do sytuacji, w której określona norma niższego rzędu będzie naruszała zasadę, w takim stopniu, iż będzie można mówić o sprzeczności między normą zasadą a normą regułą - zob. przykłady podane w: Smolak (2016): 40-53. 
nicza stanowi inaczej. Kwestią nie do końca jasna jest jednak to, jak interpretować ten przepis w sytuacji wystapienia konfliktu pomiędzy treścią konstytucji a ustawa. W szczególności wątpliwości budzi to, czy w procesie wykładni prawa dopuszczalne pozostaje posłużenie się regułą lex superior derogat legi inferiori, z powołaniem na zasadę nadrzędności konstytucji ${ }^{13}$.

Ustawy, zgodnie z orzecznictwem Trybunału Konstytucyjnego (TK), korzystaja z domniemania konstytucyjności, sądy powszechne zaś nie są upoważnione do badania zgodności ustaw z konstytucja, jest to wyłączną kompetencją Trybunału ${ }^{14}$. W licznych orzeczeniach Trybunał wskazuje jednak na konieczność dokonywania wykładni ustaw przez sądy powszechne w zgodzie z konstytucją (dokonywania wykładni prokonstytucyjnej) ${ }^{15}$. Zaznacza również, że wydanie orzeczenia o niekonstytucyjności przepisów ustawy nie powinno następować w sytuacji, gdy możliwe jest nadanie im takiego rozumienia, które doprowadzi do ich zgodności z normami, zasadami i wartościami ustanowionymi przez konstytucję ${ }^{16}$. Z orzecznictwa TK wynika więc, że wykładnię prokonstytucyjną należy stosować, gdy brzmienie przepisu nie jest jednoznaczne i zachodzi możliwość jego interpretacji w różny sposób. Gdy zaś treść przepisu jest jednoznaczna, ale pozostaje sprzeczna z konstytucja, właściwą metodą postępowania powinno być uchylenie takiego przepisu. Trybunał wskazuje więc, że granicą posługiwania się metodą wykładni ustawy w zgodzie z konstytucją pozostaje językowe brzmienie przepisu ustawy ${ }^{17}$. Wyklucza on tym samym dopuszczalność przełamania rezultatów wykładni językowej.

Podobne stanowisko bywa prezentowane również przez doktrynę ${ }^{18}$. Andrzej Bator, który sam go nie podziela, czyniąc próbę krótkiego podsumowania najważniejszych tez przedstawianych w tym zakresie, zwraca uwagę na argumentację odwołująca się do: (1) gwarancyjnego, a nie kompetencyjnego charakteru art. 178 ust. 1 Konstytucji $\mathrm{RP}^{19}$, (2) brzmienia art. 190 ust. 3 Konstytucji RP, z którego wynika, że orzeczenie o niekonstytucyjności wchodzi w życie dopiero z dniem ogłoszenia, co sprawia, iż na gruncie tego przepisu można twierdzić, że do tego momentu ustawę, choćby sprzeczną z konstytucja, należy w dalszym ciagu stosować, (3) poglądów, że odmowa zastosowania ustawy prowadziłaby do przekroczenia przez sądy granicy stosowania prawa (orzeczenia sądów miałyby charakter prawotwórczy) ${ }^{20}$. Powyższe przesłanki skłaniają część doktryny do przyjęcia, że ustawę niezgodną z konstytucja

13 Tuleja (2003): 92; Preisner (2003): 238.

${ }^{14}$ Zob m.in. wyrok TK, P 4/99.

${ }_{15}$ Wyrok TK z 5 stycznia 1999 r., K 27/98.

${ }^{16}$ Wyrok TK z 18 października 1994 r., K 2/94.

${ }_{17}$ Skalimowski (2013): 299; Mączyński, Łyszkowska (2005): 48.

18 Garlicki (1999): 16 i 27. Podsumowanie poglądów w tym zakresie zob. m.in.: Jaskiernia (2018): 97; Mastalski (1999): 46.

${ }^{19}$ Zgodnie z art. 178 ust. 1 Konstytucji RP: „Sędziowie w sprawowaniu swojego urzędu sa niezawiśli i podlegają tylko Konstytucji oraz ustawom”. Bator zwraca jednak uwagę, że taka argumentacja pomija znaczenie art. 8 ust. 1 Konstytucji RP, wskazując, iż ustalenie relacji pomiędzy powyższymi przepisami wymaga przyłożenia ich do okoliczności konkretnej sprawy.

${ }^{20}$ Bator (2018): 120. 
należy stosować, do momentu jej uchylenia przez Trybunał Konstytucyjny. Skutki przyjęcia takich poglądów dobrze oddaje stanowisko Macieja Zielińskiego, który wskazuje, że „w przypadku gdy dany przepis (a dokładnie otrzymane z niego wyrażenie normokształtne) jest językowo jednoznaczny, konflikt treści otrzymanej zeń normy z treścią normy aktu hierarchicznie wyższego - w myśl naszego systemu prawnego - musi być rozstrzygany nie jako problem interpretacyjny (przez dostosowanie sensu "normy niższej« do "normy wyższej«), ale jako problem walidacyjny - podlegajacy kompetencji Trybunału Konstytucyjnego. Można w związku z tym stwierdzić, że bez Trybunału Konstytucyjnego sprawa ta byłaby rozstrzygana przede wszystkim w drodze interpretacji, natomiast w związku z funkcjonowaniem Trybunału Konstytucyjnego musi być rozstrzygnięta nie przez interpretatora, lecz przez Trybunał Konstytucyjny - i to przez pozbawienie "normy niższej« waloru obowiązywania"21. Poglądy o niedopuszczalności pomijania jednoznacznych przepisów ustawy w procesie stosowania prawa dominują również w orzecznictwie sądów administracyjnych ${ }^{22}$.

Mimo takiego orzecznictwa Trybunału i przedstawionych poglądów istotna część przedstawicieli doktryny, wypowiadając się o zasadach wykładni prawa, skłania się do dopuszczenia przełamania granicy językowej wykładni, a także dopuszczenia stosowania analogii właśnie w przypadku, gdy literalne stosowanie prawa prowadzi do jego sprzeczności z fundamentalnymi zasadami konstytucyjnymi, do rozstrzygnięcia, które w świetle powszechnie akceptowalnych wartości pozostaje rażąco niesłuszne, niesprawiedliwe czy nieracjonalne ${ }^{23}$. Opowiada się więc ona - w opozycji do m.in. Trybunału Konstytucyjnego - za możliwością dopuszczenia wykładni prowadzącej do wyjścia poza możliwe językowe rozumienie tekstu ustawy. Niewątpliwie może mieć to pewien związek z prezentowanymi równolegle w doktrynie poglądami o zasadności przyjęcia rozproszonego modelu badania konstytucyjności polegającego na przyznaniu organom i sądom prawa do pomijania w konkretnej sprawie stosowania norm niezgodnych z konstytucją ${ }^{24}$. Poglądy o dopuszczalności niestosowania przepisów niezgodnych z konstytucją przez sądy prezentowane sa również w orzeczeniach Sądu Najwyższego ${ }^{25}$.

To, co w kontekście powyższego sporu wydaje mi się istotne, to zwrócenie uwagi na dwa potencjalne wymiary niekonstytucyjności przepisu.

${ }^{21}$ Zieliński (2017): 262. Z drugiej strony ten sam autor, formułując dyrektywy percepcyjnej fazy wykładni, dopuszcza przełamanie językowej jednoznaczności przepisu na podstawie kryteriów funkcjonalnych, w szczególności gdy językowe znaczenie burzy określone wartości - Zieliński (2017): 301-302. Zestawienie ze sobą tezy o dopuszczalności przełamania językowo jednoznacznych rezultatów wykładni na podstawie odwołania do wartości oraz tezy o niedopuszczalności przełamania takiej wykładni zgodnie z dyrektywami systemowymi wydaje mi się kontrowersyjne. Podstawowym źródłem informacji o wartościach preferowanych przez ustawodawcę jest przecież konstytucja, a odwołanie się do niej wymaga zastosowania dyrektyw systemowych.

${ }^{22}$ Kabat (2005): 108.

${ }^{23}$ Zob. m.in. Morawski (2010): 193 i 228; Zieliński (2017): 301; Płeszka (1997): 77; Preisner (2003): 243.

${ }^{24}$ Obszernie na ten temat: Gutowski, Kardas (2017): 573-625.

${ }^{25}$ Sanetra (2005): 82. 
Po pierwsze, niezgodność z ustawą zasadniczą może dotyczyć szerokiego zakresu sytuacji stosowania normy. W szczególności może być ona możliwa do identyfikacji już na etapie analizy normy abstrakcyjnej, wynikającej z przepisów ustawy, bez przykładania treści normy do konkretnego stanu faktycznego. Jeżeli taka sprzeczność zostanie zidentyfikowana, przepis niewątpliwie powinien podlegać derogacji. Trudno uznać bowiem za poprawna sytuację, gdy w systemie prawnym funkcjonuje przepis fundamentalnie niezgodny z treścią ustawy zasadniczej. Niezależnie od tego, czy uznamy, że sądy powszechne mają możliwość jego pomijania, czy też nie, to przejrzystość prawa wymagałaby jego formalnego uchylenia, by fakt jego występowania w treści aktu normatywnego nie wprowadzał obywateli w błąd. Po drugie, sprzeczność efektu zastosowania normy z konstytucją może wystapić w okolicznościach danej konkretnej sprawy, ze względu na szczególne okoliczności w niej występujące. Niekonstytucyjność przepisu może mieć więc charakter zakresowy. Inaczej mówiąc, możemy mieć do czynienia z sytuacją, w której stosowanie określonego przepisu co do zasady będzie prowadziło do rezultatów pozostających $\mathrm{w}$ zgodzie $\mathrm{z}$ uregulowaniami konstytucyjnymi, niemniej w pewnym zakresie stanów faktycznych interpretacja regulacji w granicach możliwego sensu językowego użytych przez ustawodawcę wyrażeń będzie skutkowała efektami niezgodnymi z ustawą zasadnicza. Niejednokrotnie zakres, w jakim stosowanie przepisu będzie skutkowało efektami sprzecznymi z konstytucja, może pozostawać wąski i być trudny do zidentyfikowania, inaczej niż przy analizie konkretnego przypadku.

W tym kontekście wskazać należy, że biorąc pod uwagę złożoność zjawisk społecznych, nie można oczekiwać, że ustawodawca przewidzi, stanowiąc przepis, który ma charakter abstrakcyjny, wszystkie możliwe sytuacje, do których znajdzie on zastosowanie, i tak go doprecyzuje, by rozgraniczał on wszelkie możliwe stany faktyczne. To właśnie proces wykładni służyć powinien weryfikacji, czy zastosowanie normy do konkretnego przypadku daje oczekiwane rezultaty. Stąd też, jak sądzę, niekonstytucyjność rezultatów zastosowania konkretnego przepisu w danych okolicznościach, której z jednej strony nie da się wyeliminować przez wybór spośród oferowanych przez język tekstu prawnego alternatyw interpretacyjnych, a z drugiej - która nie odnosi się do szerszego katalogu przypadków, musi siłą rzeczy być korygowana w procesie stosowania prawa (jego wykładni) przez sądy, a nie w procesie derogacji.

Uwzględnienie w procesie wykładni prawa wartości konstytucyjnych jest więc, moim zdaniem, konieczne nie tylko w takim zakresie, w jakim pozwala na to językowe brzmienie tekstu aktu normatywnego, ale również w tych przypadkach, w których rozstrzygnięcie problemu na podstawie literalnie odczytywanego tekstu ustawy prowadziłoby do akceptacji rozstrzygnięcia niesłusznego, niezgodnego z aksjologia ustawodawcy implementowaną do systemu prawnego przez przepisy konstytucji. Możliwość odwołania się w procesie stosowania prawa do wartości postrzegać należy jako swego rodzaju zawór bezpieczeństwa, umożliwiający przeciwdziałanie sytuacji, gdy literalnie stosowane prawo staje się źródłem niesprawiedliwości (summum ius, summa iniuria). 
Wydaje się przy tym, że nie zawsze generalna kompetencja Trybunału Konstytucyjnego do badania konstytucyjności norm in abstracto będzie odpowiednia do rozwiązania konkretnego problemu prawnego, przed którym stanie sąd powszechny. Jak słusznie zwraca uwagę Sąd Najwyższy: „inny jest bowiem przedmiot orzekania [sądów powszechnych i Trybunału Konstytucyjnego - M.K.] i wynikajace z tego skutki. Trybunał orzeka o prawie i jest władny uchylić przepis ustawy, a jego orzeczenie jest powszechnie obowiązujące i ostateczne (art. 190 Konstytucji). Sąd natomiast orzeka o indywidualnym stosunku społecznym [...]"26. W doktrynie dostrzega się, że to sędziowie spoza składów TK, a w szczególności sędziowie sądów powszechnych, dysponują największą wiedzą o konkretnych stanach faktycznych i ich rzeczywistym uwikłaniu prawnym, która to wiedza jest w dużo mniejszym stopniu dostępna składom orzekającym in abstracto o konstytucyjności tworzonego prawa ${ }^{27}$. Sprawia to, że to sędziom sądów powszechnych łatwiej jest dostrzec zakresową niekonstytucyjność konkretnych regulacji. Pozbawienie ich w takiej sytuacji możliwości samodzielnej reakcji i stwierdzenia zakresowej niekonstytucyjności określonej regulacji de facto skutkowałoby koniecznościa zastapienia kontroli abstrakcyjnej, sprawowanej przez Trybunał Konstytucyjny, kontrola konkretną. Sędziowie sądów powszechnych przekonani o tym, że zastosowanie określonego przepisu w konkretnej sprawie naruszałoby wartości konstytucyjne, musieliby bowiem każdorazowo kierować pytanie prawne dotyczace konstytucyjności stosowania przepisu do Trybunału. Ten zaś, by właściwie przeanalizować problem, musiałby badać konstytucyjność stosowania przepisu, uwzględniając realia danej sprawy.

\section{MODEL ROZPROSZONEJ KONTROLI KONSTYTUCYJNOŚCI JAKO PODSTAWA OCHRONY UPRAWNIEŃ JEDNOSTKI}

Niezależnie od tego wydaje się, że zapewnienie efektywności konstytucji wymaga stosowania do niezgodnych z nią przepisów reguły lex superior derogat legi inferiori. Konstytucja stanowi bowiem w demokratycznym państwie nie tylko podstawę ustrojową funkcjonowania państwa, ale przede wszystkim implementuje do systemu prawa stanowionego kluczowe uprawnienia jednostki (m.in. prawa uznawane za naturalne) i odwołania do wartości, na których opiera się demokratyczny ład społeczny ${ }^{28}$. Pierwszeństwo jej norm nad przepisami prawa stanowionego niższego rzędu nie ma więc wyłącznie charakteru formalnego, ale znajduje również silne uzasadnienie filozoficzno-aksjologiczne. Zasada bezpośredniości stosowania konstytucji ma na celu zapewnienie jednostce poszanowania jej podstawowych praw i wolności, dla których

\footnotetext{
${ }^{26}$ Postanowienie SN z 26 maja 1998 r., III SW 1/98.

27 Bator (2018): 123.

28 Szeroko na ten temat: Kryszeń, Prokop (2017).
} 
funkcjonowania w systemie prawa pozytywnego ${ }^{29}$ konieczne jest umocowanie normatywne $\mathrm{e}^{30}$.

W tym kontekście pamiętać należy, że rolą konstytucji pozostaje ograniczenie uprawnień władzy wobec jednostki ${ }^{31}$. Dla zapewnienia efektywności takiego ograniczenia niezbędne jest, by sądy i organy stosujące prawo pomijały w procesie wykładni prawa treści aktów normatywnych niezgodnych z treścia ustawy zasadniczej. Nie sposób przyjąć przykładowo, że organ państwowy czy sąd w sytuacji ustalenia, iż ustawa prowadzi do ewidentnego naruszenia godności ludzkiej, byłyby zobowiązane do jej stosowania do momentu stwierdzenia przez Trybunał Konstytucyjny jej niekonstytucyjności. Oczywiście rozstrzygając sprawy na podstawie konstytucji, należy postulować daleko posunięta powściągliwość. Niemniej zasada jej nadrzędności nad ustawami przemawia za tym, by nie tylko Trybunał Konstytucyjny dysponował możliwością stwierdzania niekonstytucyjności ustaw. W innym przypadku konieczne mogłoby się okazać respektowanie przez sądy i organy ustaw rażąco niezgodnych z ustawą zasadniczą i naruszających fundamentalne prawa jednostki.

Analizując dopuszczalność przełamania możliwego językowego rozumienia tekstu prawnego zgodnie z zasadą nadrzędności konstytucji, należy oczywiście zwrócić uwagę na zagrożenia z tym związane. Dopuszczenie takiej sytuacji rodzi ryzyko deprecjacji znaczenia przepisów ustaw ${ }^{32}$, godząc tym samym w wartość, którą pozostaje pewność prawa. Dodatkowo sprzyja ono powstawaniu rozbieżności w interpretacji i stosowaniu konstytucji ${ }^{33}$. Dlatego też trafne pozostaje stanowisko Sądu Najwyższego, że: „zastosowanie wykładni, w której interpretator odchodzi od sensu językowego przepisu, może być uzasadnione tylko w wyjątkowych okolicznościach, ponieważ adresaci norm prawnych mają prawo polegać na tym, co ustawodawca w przepisie rzeczywiście wyraził, a nie na tym, co chciał uczynić lub co uczyniłby, gdyby znał nowe lub inne okoliczności”34.

\section{WYKŁADNIA SYSTEMOWA I FUNKCJONALNA JAKO KONIECZNY ELEMENT PROCESU INTERPRETACJI PRAWA}

Poczynione stwierdzenie, że przepisy konstytucji powinny być bezpośrednio stosowane i uwzględniane w procesie wykładni prawa przez organy i sądy oraz że w tym zakresie stosować należy regułę lex superior derogat legi infe-

${ }^{29}$ Konstytucyjne założenia odnośnie do systemu prawnego nacechowane sa pozytywizmem i nie przewidują nadrzędności żadnych reguł czy zasad ponad regułami konstytucyjnymi - zob. m.in. Safjan, Bosek (2016): 61.

${ }^{30}$ Odmiennie m.in.: Mączyński i Łyszkowska (2005): 50. Autorzy ci uważają że tezy o dopuszczalności incydentalnej odmowy zastosowania ustawy mogą pociagać za sobą następstwa niekorzystne zarówno z punktu widzenia ochrony wolności i praw jednostki, jak i wartości istotnych dla funkcjonowania systemu prawnego.

${ }^{31}$ Piotrowski (2018): 215; podobnie: Tuleja (1999): 40.

32 Janiszewska (2016): 162.

33 Safjan (1999): 38-39; Hofmański (1999): 44.

${ }^{34}$ Uchwała SN z 7 czerwca 2001 r., III CZP 29/01. 
riori, pozwala na potwierdzenie tezy, iż wyniki wykładni językowej przepisu należy w systemie prawa stanowionego zawsze uzupełnić o analizę na gruncie reguł kolizyjnych, obejmującą między innymi analizę jego zgodności z normami wyższego rzędu, wartościami i klauzulami generalnymi. To właśnie w tym procesie możliwe jest to, co nazywa się niekiedy przełamaniem językowej granicy interpretacji przepisu. Jeżeli w danej sytuacji wynik literalnej interpretacji konkretnego zespołu przepisów narusza określone wartości lub prowadzi do absurdu, to prawidłowy sposób jego zakwestionowania polegać powinien na wykazaniu tej sprzeczności bądź to na gruncie obowiązujaccych w danej dziedzinie klauzul generalnych, bądź też przez odwołanie się do przepisów aktów nadrzędnych, w szczególności tych implementujących do systemu prawnego odwołania do określonych wartości. Obie te sytuacje wymagają odrębnego omówienia.

Po pierwsze, podstawę do wyjścia poza granice językowego rozumienia konkretnego zespołu interpretowanych przepisów mogą dawać wprowadzone w danej dziedzinie przez ustawodawcę klauzule generalne. Przepisy ustanawiajace takie instytucje, jak na przykład cywilistyczny zakaz nadużycia prawa podmiotowego czy nieważność czynności stanowiącej obejście prawa, daja interpretatorowi wyraźna podstawę do odejścia od rozstrzygnięcia problemu interpretacyjnego wyłacznie zgodnie z litera zespołu interpretowanych, powiązanych ze sobą przepisów merytorycznych. Nie mamy w tym przypadku jednak do czynienia z odejściem od wykładni literalnej sensu stricto, a jedynie z uwzględnieniem dodatkowego przepisu modyfikującego o charakterze ogólnym. Biorąc jednak pod uwagę, że klauzule generalne opierają się często na zwrotach niedookreślonych (przykładowo: stosowanie cywilistycznej instytucji zakazu nadużycia prawa podmiotowego wymaga zbadania zgodności czynności cywilnoprawnej z zasadami współżycia społecznego i społeczno-gospodarczym przeznaczeniem prawa), wyróżnienie tej sytuacji wydaje się celowe. Normy te często implementuja bowiem do systemu pewne zasady prawne, których przestrzeganie ma zapewnić realizację wartości konstytucyjnych $^{35}$. Przykładowo jako cel obowiąywania zakazu obejścia prawa można postrzegać przeciwdziałanie instrumentalnemu wykorzystaniu przez jednostkę zasady prymatu wykładni językowej w celu osiagnięcia efektów niezgodnych z celem przepisów. Zakaz ten zmierza więc do urzeczywistnienia wartości konstytucyjnej, którą pozostaje roszczenie obywatela do uzyskania sprawiedliwego rozstrzygnięcia, a nie tylko uzyskania rozstrzygnięcia zgodnego z wąsko rozumianą litera prawa.

Po drugie, podstawę do przełamania językowego znaczenia zespołu interpretowanych przepisów upatruję w sytuacji, w której niemożliwe jest dokonanie takiej wykładni, w granicach wyznaczonych możliwym na gruncie językowym rozumieniem tekstu prawnego, która pozostawałaby w zgodzie z prawem nadrzędnym (w szczególności z wartościami, które przepisy nadrzędne stawiają na pierwszym miejscu). W tej sytuacji interpretator zmuszony jest do odejścia od wykładni literalnej, wskazując na sprzeczność jej efektów

${ }^{35}$ Zob. również: Pietrzykowski (2018): komentarz do art. 5 k.c. pkt VI ppkt 2. 
z przepisami wyższego rzędu, oraz poszukiwania innego rozstrzygnięcia problemu interpretacyjnego. Uważam, że to właśnie w tym procesie interpretator może zakwestionować sprzeczność określonego sposobu wykładni przepisów na przykład z wartościami, wychodząc poza możliwe językowe rozumienie tekstu aktu normatywnego. Wykazanie, że literalne brzmienie przepisu prowadzi do sprzeczności efektów jego interpretacji z normą konstytucyjną lub wartościami przez nią chronionymi (np. zasadą ochrony godności człowieka), powala mu zignorować literalne brzmienie przepisu zgodnie z zasadą hierarchiczności norm.

Taki sposób podejścia do interpretacji prawa z jednej strony czyni zadość postulatom, by w procesie interpretacji prawa uwzględniać wartości, z drugiej zaś - odpowiada idei systemu prawa stanowionego, zgodnie z którą wszelkie rozstrzygnięcia w nim dokonywane muszą znajdować uzasadnienie w treści prawa. Wartościa, którą za sobą niesie taki sposób uzasadnienia decyzji interpretacyjnych, jest to, że treść rozstrzygnięcia wywodzi się w tym przypadku z konkretnego przepisu, a więc buduje zaufanie do prawa stanowionego oraz pozytywistycznej koncepcji prawa.

Przedstawione podejście do interpretacji przepisów otwiera ciekawy wymiar dyskursu dotyczący przełamywania granicy możliwego językowego znaczenia przepisu prawnego. Prowadzi do konieczności zważenia w takim przypadku wartości konstytucyjnych, które określony, literalny sposób interpretacji przepisu narusza, z wartościa, która jest zaufanie jednostki do stanowionego przez państwo prawa ${ }^{36}$. Próby dokonywania takiego ważenia widać doskonale w orzecznictwie i doktrynie. Podnosi się przecież, że „obowiązek wykładni literalnej powinien być szczególnie rygorystycznie przestrzegany w tych przypadkach, w których wymaga tego ochrona bezpieczeństwa obywateli, którzy nie powinni być zaskakiwani rozszerzaniem lub zwężaniem sensu przepisów prawnych, w sytuacji gdy działali w zaufaniu do nich"37. Istotną rolę językowemu znaczeniu tekstu przypisuje się w takich dziedzinach, jak prawo karne czy podatkowe, w nich to wartości, do naruszenia których może potencjalnie dojść w drodze wykładni rozszerzającej czy zawężającej, sa najistotniejsze (wolność/ własność). Jednocześnie odejście od językowego brzmienia przepisu czy stosowanie analogii doktryna i orzecznictwo dopuszczają zasadniczo na korzyść jednostki, gdy wykładnia literalna nie prowadzi do naruszenia przysługujących jednostce praw i wolności.

Takie ujęcie problemu otwiera również dyskusję odnośnie do tego, jak duże znaczenie należy przypisywać prawu jednostki do odwoływania się do litery prawa w sytuacji, gdy możliwe językowe rozumienie tekstu prawnego stoi w konflikcie z innymi wartościami implementowanymi do systemu prawa ${ }^{38}$.

36 Podobnie: Spyra (2006): 270; na temat pewności prawa jako wartości konstytucyjnej zob. również: Kordela (2016): 149-160.

37 Morawski (2010): 196.

38 Rodzi ono także dalsze pytania, takie jak choćby, jakie znaczenie ma dobra wiara jednostki przy powoływaniu się przez nią na literę prawa, a więc inaczej mówiąc, czy fakt, że jednostka, świadoma, iż jej działanie prowadzi do naruszenia wartości wynikających z norm nadrzędnych, wywodzi swoje uprawnienia z litery prawa, daje podstawy do pozbawienia jej ochrony prawnej. Prima facie wydaje się, że są podstawy ku takiemu twierdzeniu, a nawet że prawo stanowione ma 
Dotyka więc problemu antynomii pomiędzy fundamentalnymi ideami prawa: jego sprawiedliwościa, celowością oraz bezpieczeństwem, które ma ono gwarantować ${ }^{39}$. O ile problem ten, na korzyść jednostki, można próbować rozstrzygnacc w relacjach państwo-obywatel, to gdy mamy do czynienia z konfliktem między obywatelami, z których jeden powołuje się na literę prawa, a drugi - na wartości wynikające z aktu nadrzędnego, jego rozwiązanie staje się zdecydowanie bardziej skomplikowane. Możliwość odwołania się w tym przypadku do ważenia wartości otwiera jednak drogę do rozstrzygania takich spraw a casu ad casum. Dodatkowo takie podejście, jako znajdujace oparcie w zasadzie hierarchiczności norm i konkretnych przepisach prawa, wpisuje się w ideę pozytywizmu prawniczego.

Ewentualne odrzucenie hipotez interpretacyjnych wynikajacych ze znaczenia językowego tekstu aktu prawnego (przełamanie możliwego językowego sposobu rozumienia tekstu prawnego) musi prowadzić oczywiście do konieczności poszukiwania innych podstaw rozstrzygnięcia danej sprawy. Podstaw tych, w mojej ocenie, należy poszukiwać w obrębie tekstów prawnych. Fakt właczenia do systemu prawnego na gruncie konstytucyjnym aksjologii pozwala na rozstrzygnięcie tzw. trudnych przypadków. Jeżeli bowiem sąd nie znajduje wyraźnej podstawy prawnej do rozstrzygnięcia określonego problemu, może on poszukiwać jego rozwiązania, odwołując się do przepisów implementujacych do porządku prawnego wartości preferowane przez ustawodawcę, w tym odwołanie się do aksjologii konstytucyjnej. Takie podejście daje sądowi możliwość uzasadnienia swojego rozstrzygnięcia przez odniesienie do konkretnych przepisów, na których oparł decyzję interpretacyjną, umożliwiając jej weryfikację w trybie instancyjnym.

\section{PODSUMOWANIE}

Podsumowując, wydaje mi się, że jeżeli akceptujemy reguły ustanowione Konstytucją RP, to musimy zakładać, że wszelkie rozstrzygnięcia prawne muszę opierać się na treści prawa stanowionego (na literze prawa). Stąd też punktem wyjścia procesu wykładni musi być tekst aktu normatywnego, a granica wykładni zasadniczo możliwy językowy sposób rozumienia słów użytych przez ustawodawcę. Prawidłowo przeprowadzony proces interpretacji, już na etapie wykładni językowej, wymaga jednak znajomości języka, którym posługuje się ustawodawca, i kontekstu funkcjonowania przepisu, co zmusza interpretatora do przeprowadzenia szerszej analizy funkcjonalnej i systemowej.

Dokonanie wykładni funkcjonalnej i systemowej jest niezbędne również ze względu na zasadę hierarchiczności aktów prawnych, w szczególności zasadę nadrzędności konstytucji. W procesie wyboru spośród możliwych znaczeń

instytucje, które mają właśnie temu służyć (np. na gruncie kodeksu cywilnego: zakaz nadużycia prawa/ obejścia prawa).

${ }^{39} \mathrm{O}$ antynomii idei prawa zob. Radbruch (2009): 79-84. 
przepisu należy bowiem nie tylko kierować się wykładnią prokonstytucyjna, ale zgodnie z regułą lex superior derogat legi inferiori odrzucać takie rezultaty wykładni, które pozostają nie do pogodzenia z zasadami konstytucyjnymi, w tym w szczególności naruszają wartości chronione ustawą zasadniczą. To w ramach tego procesu, jeżeli żaden z możliwych sposobów rozumienia tekstu prawnego na gruncie językowym nie daje się pogodzić z wynikami interpretacji treści aktów wyższego rzędu czy też wartościami, które akty te implementują do porządku prawnego - możliwe jest przełamanie możliwego na gruncie językowym znaczenia przepisu przy jego wykładni ${ }^{40}$.

Okoliczność ta sprawia, że rozważając możliwość przełamania możliwego językowego rozumienia przepisów ustawy, pojawia się zagadnienie dopuszczalności dokonania takiego przełamania przez organy inne niż Trybunał Konstytucyjny. W artykule skłaniam się do tego, że kompetencję taka powinny posiadać również inne sądy i organy. Zapewnienie efektywności zasadzie nadrzędności konstytucji wymaga bowiem zapewnienia możliwości odmowy zastosowania przepisu z nią sprzecznego na każdym etapie stosowania prawa. Choć dopuszczenie stosowania w tym przypadku zasady lex superior derogat legi inferiori niesie za sobą określone zagrożenia, to równocześnie jej odrzucenie wydaje się jeszcze groźniejsze. Może ono bowiem powodować zobligowanie organów do stosowania norm ustawowych rażąco naruszajacych fundamentalne prawa chronione regulacjami konstytucyjnymi.

Niezależnie od tego pamiętać należy, że przy przełamywaniu możliwego na gruncie językowym rozumienia przepisu, jak się wydaje, zawsze dojdzie do zderzenia ze sobą wartości konstytucyjnych. Z jednej strony na szali stanie roszczenie jednostki o prawo powoływania się na zasadę pewności prawa i zaufania do prawa stanowionego, z drugiej zaś - wartości, do których naruszenia prowadziłoby literalne odczytanie przepisu. W celu podjęcia racjonalnego rozstrzygnięcia niezbędne będzie przeprowadzenie procesu ważenia wskazanych wartości. Jedynie w sytuacji, gdy pewność prawa ustapi innym wartościom konstytucyjnym, dopuszczalne będzie przełamanie możliwego sensu językowego ustawy.

\section{Mikołaj Kondej}

Uniwersytet im. Adama Mickiewicza w Poznaniu

m.kondej@amu.edu.pl

https://orcid.org/0000-0002-9727-3931

Alexy, R. (2010). Teoria praw podstawowych. Warszawa.

Banaszak, B. (2012). Konstytucja Rzeczypospolitej Polskiej. Komentarz. Warszawa.

Banaszak, B. (1997). Proceduralne i materialnoprawne normy Konstytucji, [w:] J. Trzciński (red.),

Charakter i struktura norm Konstytucji. Warszawa: 114-124.

Banaszak, B. (2012). Konstytucja Rzeczypospolitej Polskiej. Komentarz. Warszawa.

${ }^{40}$ Przełamanie to w wielu przypadkach będzie polegało na dostosowaniu elementów treści normy niższego rzędu, np. w drodze jej wykładni zawężającej lub rozszerzającej, w taki sposób, by uczynić skutki jej zastosowania w danych okolicznościach zgodnymi z wymogami konstytucyjnymi. 
Bator, A. (2018). Ewolucja analitycznej teorii prawa a bezpośrednie stosowania konstytucji. Filozofia Publiczna i Edukacja Demokratyczna 1(7): 97-134.

Działocha, K. (2016). Komentarz do art. 8 Konstytucji, [w:] L. Garlicki, M. Zubik (red.), Konstytucja Rzeczypospolitej Polskiej. Komentarz. Warszaw: 258-323.

Filipczyk, H. (2017). Tax Avoidance and Rationality of Law. Warszawa.

Gutowski, M., Kardas, P. (2017). Wykładnia i stosowanie prawa w procesie opartym na Konstytucji. Warszawa.

Garlicki, L. (1999). Bezpośrednie stosowanie Konstytucji, [w:] Konferencja naukowa: Konstytucja RP w praktyce. Warszawa: $12-32$.

Hofmański, P. (1999). Bezpośrednie stosowanie Konstytucji, [w:] Konferencja naukowa: Konstytucja RP w praktyce. Warszawa: $44-45$.

Jaskiernia, J. (2018). Spór o reguły bezpośredniego stosowania Konstytucji RP, [w:] R. Balicki, M. Jabłoński (red.), Dookoła Wojtek... Księga pamiątkowa poświęcona Doktorowi Arturowi Wojciechowi Preisnerowi. Wrocław: 87-102.

Janiszewska, B. (2016). Z tej strony stołu - uwagi praktyka o roli orzecznictwa w systemie prawa, [w:] T. Giaro (red.), Rola orzecznictwa w systemie prawa. Warszawa: 155-172.

Kabat, A. (2005). Bezpośrednie stosowanie Konstytucji w orzecznictwie Naczelnego Sądu Administracyjnego, [w:] K. Działocha (red.), Bezpośrednie stosowanie Konstytucji Rzeczypospolitej Polskiej. Warszawa: 85-109.

Kordela, M. (2016). Pewność prawa jako wartość konstytucyjna, [w:] M. Smolak (red.), Wykładnia konstytucji. Aktualne problemy i tendencje. Warszawa: 149-160.

Kryszeń, G., Prokop, K. (2017). Aksjologia polskiej konstytucji. Warszawa.

Mączyński, A., Łyszkowska, A. (2005). Bezpośrednie stosowanie Konstytucji RP przez Trybunał Konstytucyjny, [w:] K. Działocha (red.), Bezpośrednie stosowanie Konstytucji Rzeczypospolitej Polskiej. Warszawa: 25-51.

Morawski, L. (2010). Zasady wykładni prawa. Toruń.

Pietrzykowski, K. (2018). Komentarz do art. 5 k.c., [w:] K. Pietrzykowski (red.), Kodeks cywilny. Tom 1: Komentarz. Art. 1-449 ${ }^{10}$. Warszawa: 45-69.

Piotrowski, R. (2018). Sędziowie i granice władzy demokratycznej w świetle Konstytucji RP. Ruch Prawniczy, Ekonomiczny i Socjologiczny 80(1): 215-229.

Preisner, A. (2003). Dookoła Wojtek. Jeszcze o bezpośrednim stosowaniu konstytucji RP, [w:] L. Garlicki, A. Szmyt (red.), Sześć lat Konstytucji Rzeczypospolitej Polskiej. Doświadczenia i inspiracje. Warszawa: 230-244.

Płeszka, K. (1997). Językowe znaczenie tekstu prawnego jako granica wykładni, [w:] M. Zirk-Sadowski (red.), Sześć lat Konstytucji Rzeczypospolitej Polskiej. Doświadczenia i inspiracje. Łódź: 69-77.

Radbruch, G. (2009). Filozofia prawa. Tłum. E. Nowak. Warszawa.

Mastalski, R. (1999). Bezpośrednie stosowanie konstytucji, [w:] Konferencja naukowa: Konstytucja $\mathrm{RP}$ w praktyce. Warszawa: 45-46.

Morawski, L. (2010). Zasady wykładni prawa. Toruń.

Safjan, M. (1999). Bezpośrednie stosowanie konstytucji, [w:] Konferencja naukowa: Konstytucja RP w praktyce. Warszawa: 36-40.

Safjan, M., Bosek, L. (2016). Konstytucja RP. Tom 2: Komentarz. Art. 87-243. Warszawa.

Sanetra, W. (2005). Bezpośrednie stosowanie Konstytucji RP w orzecznictwie Sądu Najwyższego, [w:] K. Działocha (red.), Bezpośrednie stosowanie Konstytucji Rzeczypospolitej Polskiej. Warszawa: 52-84.

Skalimowski, P. (2013). Granice między wykładnia prokonstytucyjną a bezpośrednim stosowaniem przepisów konstytucji - uwagi na tle uchwały Izby Gospodarczej NSA z 22 czerwca 2011 r. Palestra 3/4: 299-308.

Smolak, M. (2016). Wykładnia otoczenia normatywnego konstytucji, [w:] M. Smolak (red.), Wykładnia konstytucji. Aktualne problemy i tendencje: 15-37.

Spyra, T. (2006). Granice wykładni prawa. Znaczenie językowe tekstu prawnego jako granica wykładni. Warszawa.

Tuleja, P. (1999). Bezpośrednie stosowanie Konstytucji, [w:] Konferencja naukowa: Konstytucja RP w Praktyce. Warszawa: 40-44. 
Tuleja, P. (2003). Stosowanie Konstytucji RP w świetle zasady jej nadrzędności (wybrane problemy). Kraków.

Wronkowska, S. (2016). O niektórych osobliwościach konstytucji i jej interpretacji, [w:] M. Smolak (red.), Wykładnia konstytucji. Aktualne problemy i tendencje. Warszawa: 15-37.

Wróblewski, J. (1990). Rozumienie prawa i jego wykładnia. Wrocław.

Zieliński, M. (2017). Wykładnia prawa. Zasady - reguły - wskazówki. Warszawa.

Ziembiński, Z. (1969). Kompetencja i norma kompetencyjna. Ruch Prawniczy, Ekonomiczny i Socjologiczny 31(4): 23-41.

\section{DISREGARDING THE RESULTS OF LINGUISTIC INTERPRETATION BASED ON THE PRINCIPLE OF THE SUPREMACY OF THE CONSTITUTION}

\section{Sum mary}

The article analyses the possibility of adopting a pro-constitutional interpretation of legal provisions, rather than following the conclusions of linguistic interpretation focused on alternative ways of understanding the expressions used by the legislator in the content of provisions. The author argues that the principle of the hierarchy of legal acts and the supremacy of the Constitution - combined with the fact that this basic law implements an axiology in the legal system which is the basis for the functioning of a democratic state ruled by law - entails that when the literal application of a provision would lead to results contrary to constitutional principles or values, the principle lex superior derogat legi inferiori should be applied, which permits stepping outside the borders of linguistic interpretation.

Keywords: borders of linguistic interpretation; breaking linguistic borders; hierarchy of the legal system; supremacy of the Constitution; direct application of the Constitution; lex superior derogat legi inferiori; interpretation 